\title{
Evaluation of dry matter accumulation of maize (Zea mays L.) hybrids
}

\author{
Karina Bianka Bodnár - Seyed Mohammad Nasir Mousavi - János Nagy \\ University of Debrecen Faculty of Agricultural and Food Sciences and Environmental Management, \\ Institute of Land Use, Technology and Regional Development, Debrecen \\ bodnar.karina@agr.unideb.hu
}

\begin{abstract}
SUMMARY
The increase of the grain yield of maize is closely correlated with its seasonal dry matter accumulation. Dry matter is accumulated into the grain yield during the grain filling period. The following maize hybrids were involved in the experiment: Armagnac FAO 490, Loupiac FAO 380 and Sushi FAO 340. In order to determine dry matter content, two samples per week were taken on the following days: $22^{\text {nd }}, 25^{\text {th }}, 28^{\text {th }}$, $31^{\text {st }}$ August, $4^{\text {th }}, 7^{\text {th }}, 14^{\text {th }}, 18^{\text {th }}, 22^{\text {nd }}, 25^{\text {th }}, 29^{\text {th }}$ September and $2^{\text {nd }}, 6^{\text {th }}, 9^{\text {th }}, 13^{\text {th }}$ October. In the course of sampling the weight of 100 grains from the middle section of 4 ears was measured in 4 replications. Dry matter content was determined after drying to constant weight in a drying cabinet at $60^{\circ} \mathrm{C}$. Harvesting was performed on $13^{\text {th }}$ October 2017.

The daily precipitation sum was determined by local measurements, while the daily radiation and temperature data were provided by the Meteorological Observatory Debrecen of the National Meteorological Service in Budapest. Among the agrometeorological parameters, an analysis was made of the precipitation during the growing season, effective heat sums during the vegetative and generative phase, and the water supplies. The daily heat sums were determined using the algorithm proposed.

The amount of precipitation in the winter period before the 2017 growing season was $210 \mathrm{~mm}$. The soil was saturated until its field capacity. The rather dry and warm March and April had a favourable effect, but there was no worthy amount of precipitation until May (51 mm) due to the condition of the dried seedbed. Sowing was performed on the $5^{\text {th }}$ of May 2017 in a randomised small plot experiment. There was favourable precipitation and temperature during the growing season, thereby providing ideal conditions for maize development, growth and yield formation. There was near average amount of precipitation in each year. The total amount of precipitation in the summer period is 342 mm. Temperature was mostly above the average, but there was no long and extremely warm period.

The Armagnac hybrid reached its highest dry matter mass 126 days after emergence. Physiological maturity was reached sooner (on the $119^{\text {th }}$ day) in the case of Loupiac, and even sooner in the case of Sushi (116 thay).

The thousand grain weight of Sushi (which has the shortest ripening period) was $286 \mathrm{~g}$ at the time of physiological maturity, while that of Loupiac was $311 \mathrm{~g}$. Compared to Sushi, Armagnac showed $12 \mathrm{~g}$ more dry matter accumulation $(306 \mathrm{~g})$. In the case of all three examined hybrids, physiological maturity was preceded by an intensive phase, when the dynamics of dry matter accumulation was rather quick. On average, Sushi gained $2.8 \mathrm{~g}$ dry matter per day between 103 days following emergence and physiological maturity, while the same values were $3.2 \mathrm{~g}$ for Armagnac and $3.3 \mathrm{~g}$ for Loupiac.

The aim of the regression line slope is to predict the behavior of the dependent variable with the knowledge of the values and characteristics of the independent variables using the regression line equation. Furthermore, to determine how the location affected the dynamic of dry matter accumulation in the Armagnac, Loupiac and Sushi hybrids. In regression analysis, the coefficient of explanation showed that the effect of day in the Armagnac was $97 \%$, in the Loupiac $94 \%$, in the Sushi $90 \%$. The determination coefficient $\left(R^{2}\right)$ is useful in determing how the regression equation fits. But, as we have seen, the determination coefficient alone is not sufficient to verify the model's accuracy, in addition to the determination coefficient $\left(R^{2}\right)$, the normality of the data or the residuals, the variance of the variables at different levels, the independence of the data relative to time and non-oblique. Observations are evaluated for the correctness of the fitted model.

Dry matter values decreased evenly and slightly following physiological maturity. According to our research results, it was established that physiological maturity is followed by a moderate dry matter loss. Until harvesting, Armagnac lost $40 \mathrm{~g}$ of its thousand mass weight in 29 days, while the same value pairs were $69 \mathrm{~g}$ in 36 days for Loupiac and $29 \mathrm{~g}$ in 39 days for Sushi. Loupiac - which had the highest weight at the time of physiological maturity - lost the most of its dry weight; therefore, Armagnac and Sushi had higher values at the time of harvesting.
\end{abstract}

Keywords: maize, genotype, dry matter accumulation, physiological maturity

\section{INTRODUCTION}

The $43-49 \%$ of the total organic dry matter of the maize plant is stated in the kernel. The process of filling the kernels in is closely correlated with the loss of moisture content and both are influenced by a host of factors (Bellini and Fusi 1961).

Maize hybrids have different genetic background; therefore, they react differently to the effect of agrotechnical and ecological factors. There are significant differences between the natural nutrient extraction and nutrient conversion ability of hybrids (Sárvári and Bene 2015).
Yield increase is the result of physiological processes. The grain yield increase of maize is in close correlation with seasonal dry matter accumulation. Dry matter is incorporated into the grain yield during the grain filling period. Only a smaller part of dry matter incorporated before the silking period is remobilised into the grains. Hybrids with short ripening period accumulate half of all dry matter until silking and nearly the same amount until grain filling. Also, there is a difference between parental inbred lines in terms of phasal development. Compared with inbred lines, the grain filling period is longer in the case of hybrids (Berzsenyi 2009). 
Carter and Polenit (1973) claim that the maximum dry matter of the kernel ensues when the black layer appears in the kernel was a sign of physiological maturity.

The long-term experiment results of Pepó et al. (2016) show that maize is sensitive to environmental conditions (weather, soil). The temperature and water supply are significant conditions for the successful development of kernels (Kiesselbach 1950). The temperature and speed of kernel development are positively correlated (Duncan et al. 1965). A similar positive correlation was registered by Ragland et al. (1965) between temperature and ear development. Low temperature and unfavourable supply of organic compounds stimulate the development of the black layer (Daynard and Duncan 1969). At the period of kernel filling, the high temperature and defective accumulation of sugar (saccharose), the black layer appears earlier at a low maximum of dry matter and a high moisture content (Afuakwa et al. 1984, Hanft et al. 1986). Temperature and provision of organic compounds are also decisive in determining the time of physiological maturity (Wilson et al. 1973, Máthéné 1989). Cool weather delays (Hallauer and Russel 1961), high temperature $\left(>30^{\circ} \mathrm{C}\right)$ shortens the time of maturity (Badu-Apraku et al. 1983, Tollenaar and Bruulsema 1988). Low temperature is also unfavorable for dry matter accumulation (Bunting 1976), and the yield is more or less reduced (Jones et al. 1981). Water deficiency reduces the speed of accumulation of dry matter and delays the time of maturity (Quattar et al. 1987ab). After physiological maturity, weather is the most important condition. (Aldrich 1975). The filling of kernels is connected with the loss of moisture content. Until physiological maturity, active physiological process prevail (Afuakwa et al. 1984). Kang et al. (1986) showed by means of path-analysis a positive interaction between kernel filling and speed of decline in water content $\%$, which means that if the speed of kernel filling increase, water loss ensues at a higher rate (\% loss per day). The process of drying from the appearance of the black layer until harvest, Schmidt and Hallauer (1962) observed that the daily rate of water loss depends on the season. On the contrary, Hicks et al. (1976), Dobos (2003), Dobos and Szabó (2005) were unable to show the specificity of hybrids from this point of view.

\section{MATERIAL AND METHODS}

Samples were taken in location in Debrecen. The Experimental Station is situated on the Hajdúság Loess Ridge, and the soil is a lowland chernozem with lime deposits and a deep humus layer, formed on loess. It has medium hard loam texture. The soil type is a solonetz, strongly calcareous, meadow chernozem, with loam or sandy loam texture.

The following maize hybrids provided by KITE Plc. were involved in the experiment: Armagnac FAO 490, Loupiac FAO 380, Sushi FAO FAO 340. In order to determine dry matter content, two samples were taken per week on the following days: $22^{\text {nd }}, 25^{\text {th }}, 28^{\text {th }}$, $31^{\text {st }}$ August, $4^{\text {th }}, 7^{\text {th }}, 14^{\text {th }}, 18^{\text {th }}, 22^{\text {nd }}, 25^{\text {th }}, 29^{\text {th }}$ September and $2^{\text {nd }}, 6^{\text {th }}, 9^{\text {th }}, 13^{\text {th }}$ October. In the course of sampling the weight of 100 grains from the middle section of 4 ears was measured in 4 replications. Dry matter content was determined after drying to constant weight in a drying cabinet at $60{ }^{\circ} \mathrm{C}$. Harvesting was performed on $13^{\text {th }}$ October 2017.

The daily precipitation sum was determined by local measurements, while the daily radiation and temperature data were provided by the Meteorological Observatory Debrecen of the National Meteorological Service in Budapest. Among the agrometeorological parameters, an analysis was made of the precipitation during the growing season, effective heat sums during the vegetative and generative phase, and the water supplies. The daily heat sums were determined using the algorithm proposed.

The amount of precipitation in the winter period prior to the 2017 growing season was $236 \mathrm{~mm}$. The soil was saturated until its field capacity. The rather dry and warm March and April had a favourable effect, but there was no worthy amount of precipitation until May $(51 \mathrm{~mm})$ due to the condition of the dried seedbed. Sowing was performed on the $5^{\text {th }}$ of May 2017 in a randomised small plot experiment at a plant density of 70000 plants per hectare. There was favourable precipitation and temperature during the growing season, thereby providing ideal conditions for maize development, growth and yield formation. There was near average amount of precipitation in each year. The total amount of precipitation in the summer period is $342 \mathrm{~mm}$. Temperature was mostly above the average, but there was no long and extremely warm period. The positive temperature difference in July and August was close to $2{ }^{\circ} \mathrm{C}$. The mean value in August was in accordance with the multiple-year-average (Figure 1).

Thus the computation of the sum of temperature should be performed according to Gilmore and Rogers (1958), Arnold (1959, 1960), moreover, to Cross and Zuber (1972) by the following formula:

$$
\begin{gathered}
\sum_{1}^{n} T_{a}=\left(\frac{\operatorname{Max}-\operatorname{Min}}{2}\right)-T_{B} \quad{ }^{\circ} \mathrm{C} \\
\mathrm{T}_{\mathrm{B}}=10^{\circ} \mathrm{C}
\end{gathered}
$$

where $\Sigma \mathrm{T}_{\mathrm{a}}$ is the sum of the active temperatures throughout the growing season, the expression of the fraction corresponds to the mean value of daily mean temperature, and the $T_{B}$ is the basic temperature. The value of the degree-day is obtained by the formula:

$$
\begin{gathered}
\text { degree - day }=\left[\left(\frac{M a x-M i n}{2}\right)-T_{B}\right] \quad{ }^{\circ} C d a y^{-1} \\
\mathrm{~T}_{\mathrm{B}}=10^{\circ} \mathrm{C}
\end{gathered}
$$


Figure 1: Monthly mean temperature and precipitation in 2016 and 2017

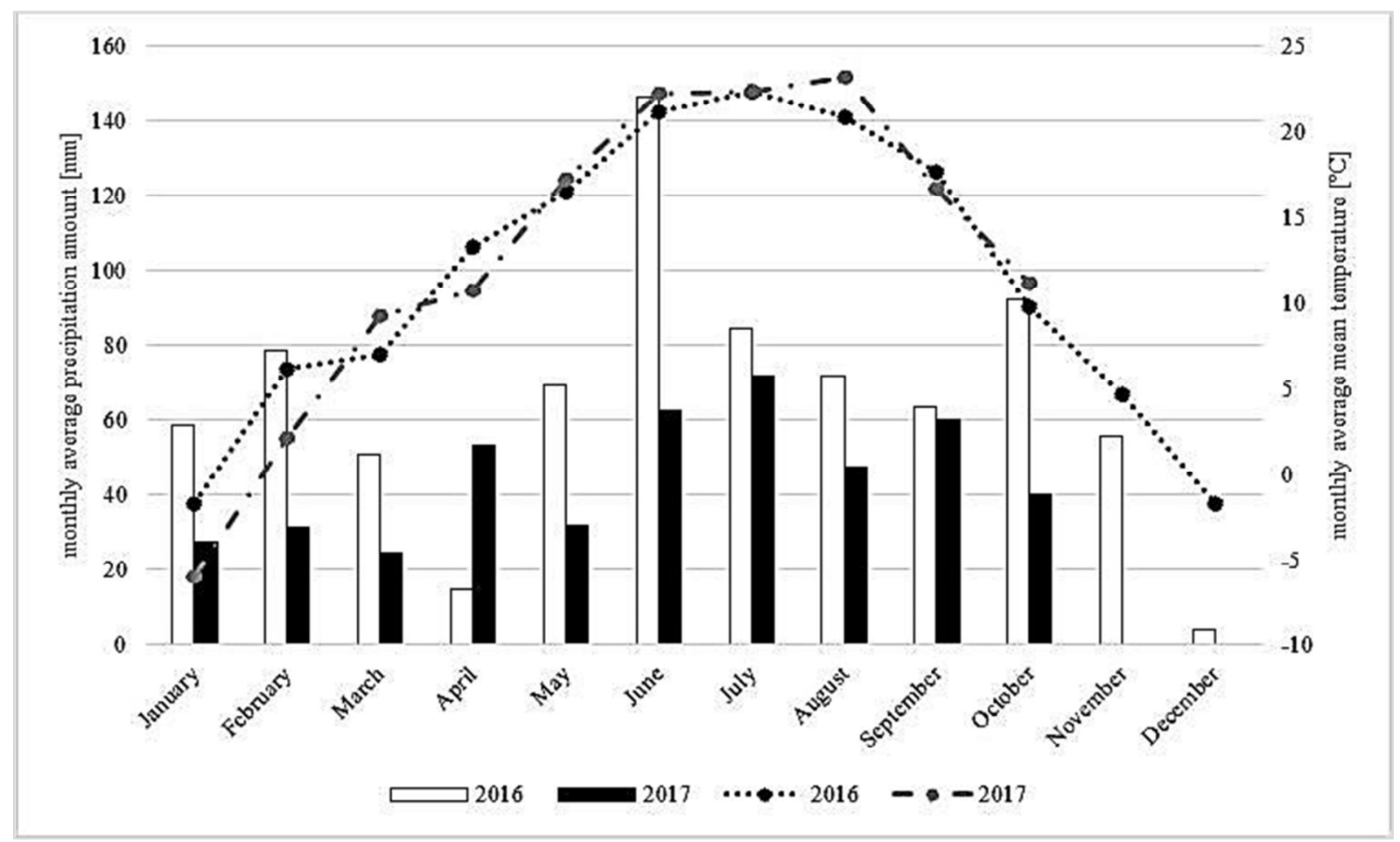

The most accepted one is proposed by Gilmore and Rogers (1958) based on a regression analysis, which postulates that the growth is linear during the first phase of development - being demonstrated relatively well - and the horizontal axis of the graph is the temperature. The vertical axis is assigned to the volume or height of the plants. The intersection of (linear) growth with the horizontal axis (x) indicates the base temperature.

Another method using a more reliable database is proposed by Szász and Nagy (unpublished). The distribution of probability of growth over temperature gives an asymmetric $B$-distribution, hence the $B$-model of the distribution.

As far as the lower value of the daily variation of temperature is above the base temperature, in order to establish the active values of temperature, we must know the temperature below which the values ought to be omitted when making the sum. This value is generally found by statistical methods from the database of climatological observations applying a cubic equation, which describes the variation of the latter value until the end of the flowering period (Tollenaar et al. 1979, Ritchie et al. 1994).

In Hungary, $10-12{ }^{\circ} \mathrm{C}$ daily variation is nearly constant at least from the point of view of the phenological phases of maize; according to our studies this is the case also in other regions. Detailed investigations were performed in Canada, USA, in Western and Eastern Europe. Extended climatological analyses revealed that in the region of $40-46^{\circ}$ latitude of North America the daily variation of the temperature during the vegetative phase of vegetative development of maize (May-July) was around $12{ }^{\circ} \mathrm{C}$, and the difference between the regions referred to was some tenth of degrees only, whereas in Western Europe - e.g. England, where maize is grown - daily variation is $6.5^{\circ} \mathrm{C}$. In Western Europe the variation is 10.0-11.0 ${ }^{\circ} \mathrm{C}$, in Southern Europe 6.0-8.0 ${ }^{\circ} \mathrm{C}$, respectively. After all, the question of base temperature ought to be solved by different approaches in those regions.

Evaluation statistics used by Minitab and MS Excel software.

\section{RESULTS AND DISCUSSION}

Phenological measurements were performed on hybrids of various height and their most typical characteristics were collected (Table 1). The average height of Armagnac was $236 \mathrm{~cm}$, while Loupiac was $10 \mathrm{~cm}$ taller. Based on our measurements, Sushi was the tallest $(250 \mathrm{~cm})$. The number of leaves were 13 in the case of the two smaller hybrids and 12 in the case of Sushi. Based on the results measured in our experiment, the average ear length of Armagnac is 15 $\mathrm{cm}$. The ears of Loupiac and Sushi were significantly longer $(21 \mathrm{~cm}$ and $20 \mathrm{~cm}$, respectively).

Maize hybrids of different genotype can be considered mature from the physiological aspect once dry matter accumulation reaches its maximum value. The connection between grain and cob, as well as water and nutrient transport disappears with the formation of the black layer. The Armagnac hybrid 
reached its highest dry matter weight on the $126^{\text {th }}$ day following emergence. The physiological maturity was sooner in the case of Loupiac $\left(119^{\text {th }}\right.$ day) and even sooner in the case of Sushi $\left(116^{\text {th }}\right.$ day).

Table 1

Phenological indexes of maize hybrids of different genotype (Debrecen, 2017)

\begin{tabular}{lccc}
\hline & Armagnac & Loupiac & Sushi \\
\hline Height $(\mathrm{cm})$ & 236 & 245 & 250 \\
Number of nodes & 13 & 13 & 13 \\
Stem diameter (mm) & 14 & 15 & 13 \\
Number of leaves & 13 & 13 & 12 \\
Ear length $(\mathrm{cm})$ & 15 & 21 & 20 \\
Ear diameter $(\mathrm{mm})$ & 35 & 45 & 45 \\
Number of rows per ear & 17 & 16 & 15 \\
Number of grains per row & 25 & 36 & 38 \\
\hline
\end{tabular}

Armagnac is a mid-ripening dent maize hybrid (FAO 490) for grain use purpose. The average plant height of Armagnac is $236 \mathrm{~cm}$. Armagnac is a mid-tall hybrid. The ear is connected to the stem at an average height of $91 \mathrm{~cm}$. The ears are elongated and they develop 16 rows of grain and the developed ears are fully covered with grains. The initial development (at the age of 2-4 leaves) of the hybrid is weaker than average and its early development (5-8 leaves) can be considered average. The hybrid has strong foliage and stem. Its roots are strong and its stem calls for attention in the late phase of the season (especially if the predominant conditions were favourable in the flowering period). Stem breaking can be minimised with early harvesting. This hybrid has high grain quality. The pistil has no antocyanic coloration, while the cob has antocyanic colour. The hybrid has a high thousand grain weight of $350 \mathrm{~g}$. It is a flexible hybrid recommended to be sown early. Its agronomical traits are adequate and its hectolitre weight is higher than the average. The hybrid has outstanding nutrient reaction and it is recommended for intensive production. It has good water losing characteristics and its grain moisture content at harvesting is $18.1 \%$. Armagnac can be characterised by high yield level, stability and drought resistance. The hybrid's yield potential is similar to that of DKC5276 both at low and high yield levels. Armagnac has outstanding dynamics of dry matter accumulation and the range of accumulation dynamics is wide (Figure 2).

Figure 2: Dynamics of dry matter accumulation of Armagnac until physiological maturity (Debrecen, 2017)

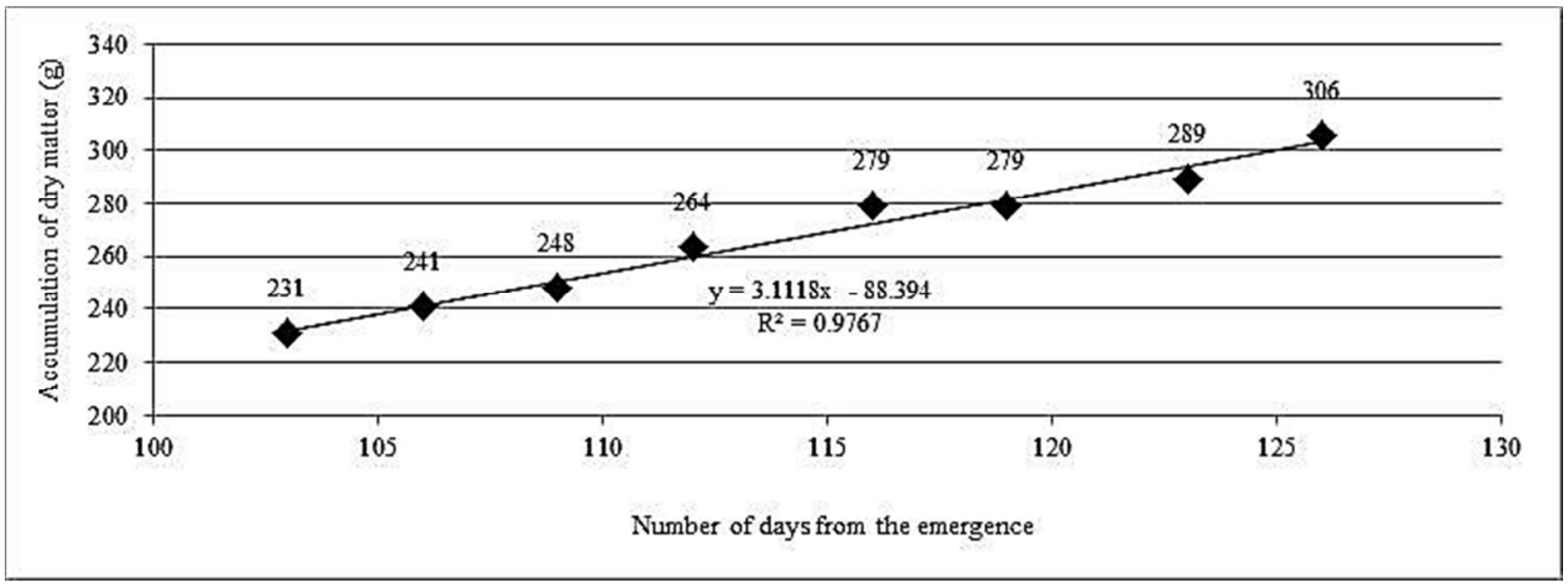

Loupiac is a dent maize hybrid for grain use purpose. The hybrid belongs to the late end of the mid-ripening group (FAO 380). Loupiac is a favourable hybrid in terms of its phenotype and its flowering takes place one day later than the group average of FAO 380 hybrids. It has a compact structure: its average plant height is $245 \mathrm{~cm}$, which makes it shorter than the average. The ear is connected to the stem at a relatively short position at $78 \mathrm{~cm}$. This hybrid develops large, elongated, cone-shaped ears with 16 rows of grain and the ear end is properly covered with grains. Its root and stem provides proper stability and its stamina is above average. Its early development is average. Loupiac is not a stay-green type of maize and the stem may have antocyanic coloration by the end of the season. The agronomical characteristics of Loupiac are good and its hectolitre weight is higher than the average. Early and optimal sowing dates are recommended. Its grain weight is above average: its thousand grain weight is around 419 g. The hybrid's grain moisture content at harvesting is $15.8 \%$. It has good yield potential and drought resistance, similarly to hybrids DKC4795 and PR37N01. The intensive phase of the grain filling of Loupiac started off from a high value $(258 \mathrm{~g})$ and it lasted for 16 days (Figure 3).

Sushi is a dent maize hybrid for grain use purpose belonging to the early ripening group (FAO 340). Sushi is a strong, mid-tall hybrid of an average height of $250 \mathrm{~cm}$ with a strong stem. The ear is connected to the stem at an average height of $101 \mathrm{~cm}$. The hybrid has a stable structure and develops elongated, flexible, 
cone-shaped ears with 16 rows of grain properly covered with grains. Sushi has favourable root and stem characteristics. The initial development of the hybrid is outstanding. The agronomical characteristics of the hybrid can be considered average, its emergence rate, early development and hectolitre weight are adequate. The hybrid can be characterised by especially high thousand grain weight of $361 \mathrm{~g}$ on average. Due to its flexible ear type and average drought resistance, it is recommended to set crop density lower. The compensation ability of Sushi is favourable. Its grain moisture content is $18.8 \%$. Sushi has especially high yield potential, similarly to DKC4014. It is not among the best hybrids in terms of drought resistance. Its dry matter accumulation interval is the shortest (13 days) and its exposure to drought is also the lowest (Figure 4).

Figure 3: Dynamics of dry matter accumulation of Loupiac until physiological maturity

(Debrecen, 2017)

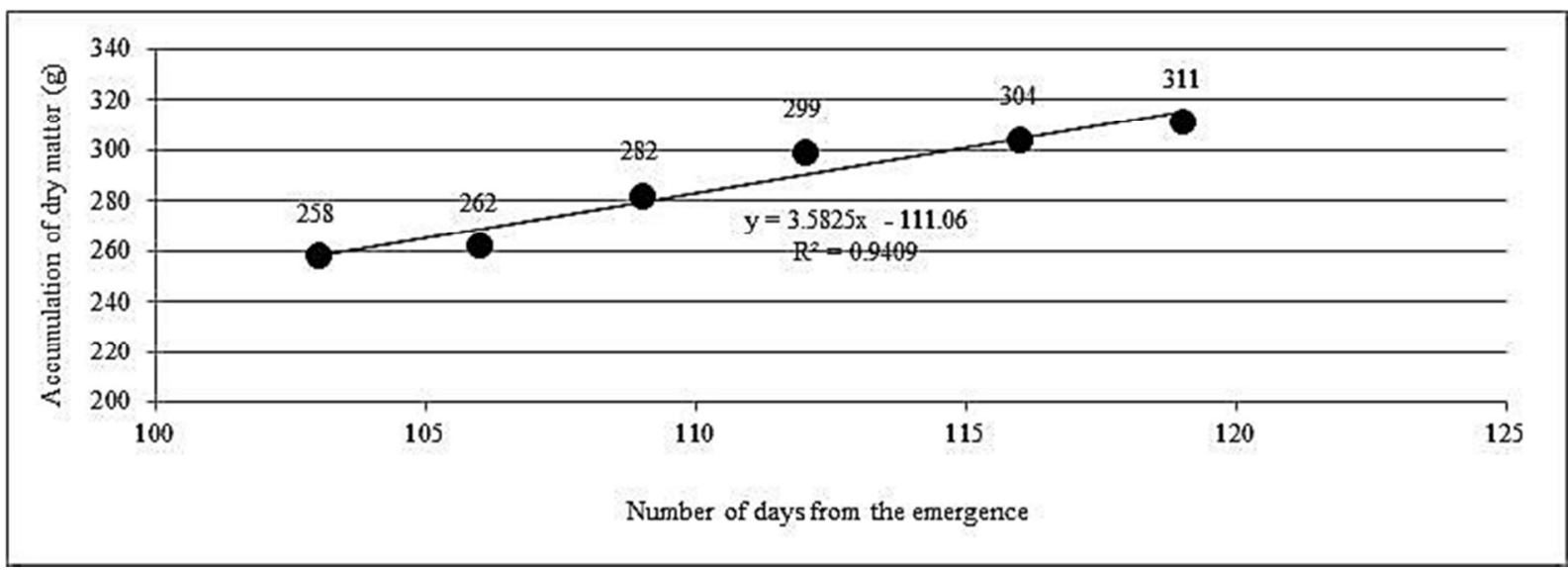

Figure 4: Dynamics of dry matter Accumulation of Sushi until physiological maturity

(Debrecen, 2017)

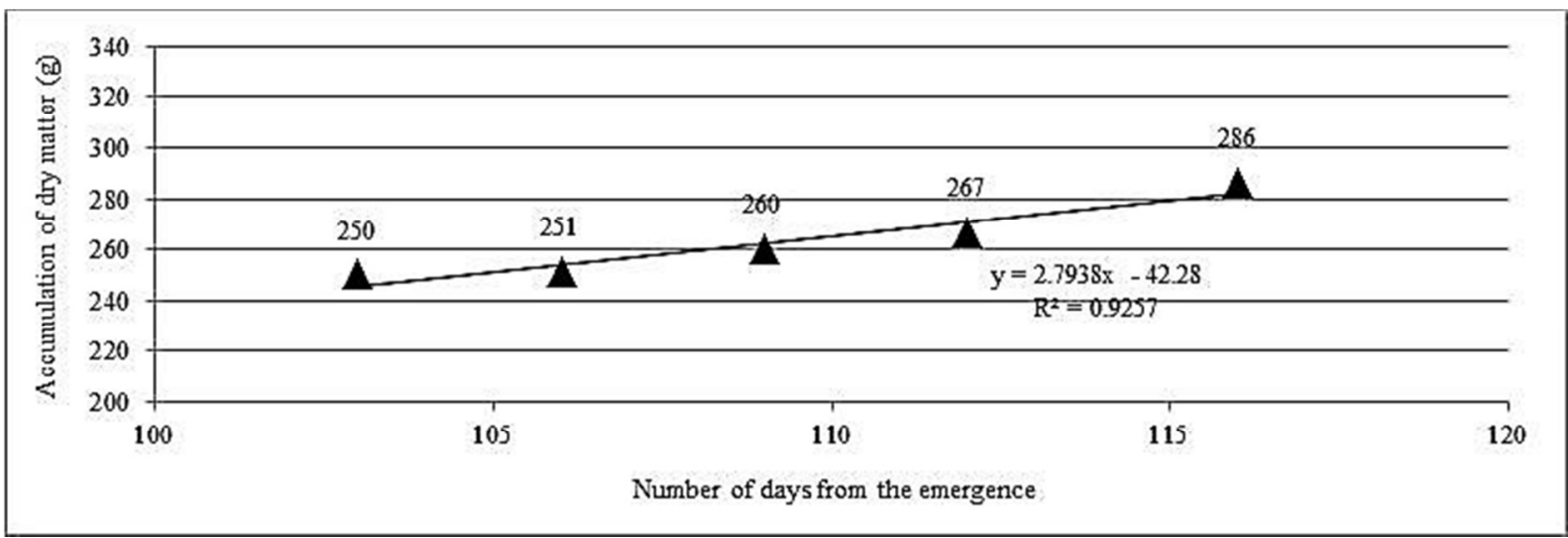

The thousand grain weight of Sushi (which has the shortest ripening period) was $286 \mathrm{~g}$ at the time of physiological maturity, while that of Loupiac was 311 g. Compared to Sushi, Armagnac showed $12 \mathrm{~g}$ more dry matter accumulation (306 g). In the case of all three examined hybrids, physiological maturity was preceded by an intensive phase, when the dynamics of dry matter accumulation was rather quick. On average, Sushi gained $2.8 \mathrm{~g}$ dry matter per day between 103 days following emergence and physiological maturity, while the same values were $3.2 \mathrm{~g}$ for Armagnac and $3.3 \mathrm{~g}$ for Loupiac. In other words, hybrids reached the highest dry matter content with different intensity (Table 2).
The aim of the regression line slope is to predict the behaviour of the dependent variable with the knowledge of the values and characteristics of the independent variables using the regression line equation. Furthermore, to determine how the location affected the dynamic of dry matter accumulation in the Armagnac, Loupiac and Sushi hybrids. In regression analysis, the coefficient of explanation showed that the effect of day in the Armagnac was $97 \%$, in the Loupiac 94\%, in the Sushi 90\%. The determination coefficient $\left(\mathrm{R}^{2}\right)$ is useful in determining how the regression equation fits. But, as we have seen, the determination coefficient alone is not sufficient to verify the model's accuracy, in addition to the determination coefficient $\left(\mathrm{R}^{2}\right)$, the normality of the 
data or the residuals, the variance of the variables at different levels, the independence of the data relative to time and non-oblique Observations are evaluated for the correctness of the fitted model (Table 3).

Table 2

Maximum dry matter and moisture content of the thousand grain weight of maize hybrids of different genotype at the time of physiological maturity (Debrecen, 2017)

\begin{tabular}{lcccc}
\hline Hybrid & $\begin{array}{c}\text { FAO } \\
\text { No. }\end{array}$ & $\begin{array}{c}\text { Maximum } \\
\text { dry matter } \\
(\mathrm{g})\end{array}$ & $\begin{array}{c}\text { Day of } \\
\text { physiological } \\
\text { maturity since } \\
\text { emergence }\end{array}$ & $\begin{array}{c}\text { Moisture } \\
(\%)\end{array}$ \\
\hline Armagnac & 490 & 306 & 126 & 28.7 \\
Loupiac & 380 & 311 & 119 & 30.4 \\
Sushi & 340 & 286 & 116 & 33.3 \\
\hline
\end{tabular}

Thousand grain dry matter weight of maize hybrids of different genotype with a regression equation

(Debrecen, 2017)

\begin{tabular}{lccc}
\hline \multicolumn{1}{r}{ Hybrid } & FAO No. & Regression equation & $\mathrm{R}^{2}$ \\
\hline Armagnac & 490 & $3.118 \mathrm{x}-88.394$ & 0.97 \\
Loupiac & 380 & $3.552 \mathrm{x}-111.06$ & 0.94 \\
Sushi & 340 & $2.7938 \mathrm{x}-42.28$ & 0.91 \\
\hline
\end{tabular}

Dry matter values decreased evenly and slightly following physiological maturity. According to our research results, it was established that physiological maturity is followed by a moderate dry matter loss. Until harvesting, Armagnac lost $40 \mathrm{~g}$ of its thousand mass weight in 29 days, while the same value pairs were $69 \mathrm{~g}$ in 36 days for Loupiac and $29 \mathrm{~g}$ in 39 days for Sushi. Loupiac - which had the highest weight at the time of physiological maturity - lost the most of its dry weight; therefore, Armagnac and Sushi had higher values at the time of harvesting.

The harvested yield of Sushi was $10.98 \mathrm{t} \mathrm{ha}^{-1}$, that of Loupiac was $12.09 \mathrm{t} \mathrm{ha}^{-1}$ and the yield of Armagnac was $12.16 \mathrm{t} \mathrm{ha}^{-1}$ (14\% moisture content). The grain moisture content at harvesting was 16.3, 15.9 and $18.1 \%$, respectively (Table 4).

Table 4

Physiological maturity time, yield elements and results of maize hybrids of various genotype

(Debrecen, 2017)

\begin{tabular}{lccc}
\hline & Armagnac & Loupiac & Sushi \\
\hline Time of physiological maturity & $14 / 9$ & $7 / 9$ & $4 / 9$ \\
Thousand grain weight $(\mathrm{g})$ & 306 & 311 & 286 \\
Grain weight per ear $(\mathrm{g})$ & 158.9 & 254.3 & 210 \\
Number of grains per ear (pcs) & 429 & 578 & 572 \\
Yield at 14\% moisture content $\left(\mathrm{t} \mathrm{ha}^{-1}\right)$ & 12.16 & 12.09 & 10.98 \\
Grain moisture at harvesting (\%) & 18.1 & 15.9 & 16.3 \\
Cob weight $(\mathrm{g})$ & 31 & 38.9 & 35.2 \\
Corn/cob ratio (\%) & 80.5 & 84.7 & 83.2 \\
\hline
\end{tabular}

\section{CONCLUSIONS}

Dry matter values decreased evenly and slightly following physiological maturity. According to our research results, it was established that physiological maturity is followed by a moderate dry matter loss. Until harvesting, Armagnac lost $40 \mathrm{~g}$ of its thousand mass weight in 29 days, while the same value pairs were $69 \mathrm{~g}$ in 36 days for Loupiac and $29 \mathrm{~g}$ in 39 days for Sushi. Loupiac - which had the highest weight at the time of physiological maturity - lost the most of its dry weight; therefore, Armagnac and Sushi had higher values at the time of harvesting.

The aim of the regression line slope is to predict the behavior of the dependent variable with the knowledge of the values and characteristics of the independent variables using the regression line equation. Observations are evaluated for the correctness of the fitted model.

\section{ACKNOWLEDGEMENTS}

The publication is supported by the EFOP-3.6.3VEKOP-16-2017-00008 project. The project is cofinanced by the European Union and the European Social Fund.

\section{REFERENCES}

Afuakwa, J. J.-Crookstone, K. R.-Jones, R. J. (1984): Effect of temperature and sucrose availability on kernel black layer development in maize. Crop Science. 24: 285-288.

Aldrich, S. R.-Leng, E. R. (1975): Modern corn production. Illinois, USA. 8-25.

Arnold, C. Y. (1959): The determination and significance of the base temperature in a linear heat unit system. Proc. Amer. Soc. Hort. Sci. 74: 430-445.

Arnold, C. Y. (1960): Maximum-minimum temperatures as a basis for computing heat unit. Proc. Amer. Soc. Hort. Sci. 76: 682692

Badu-Apraku, B.-Hunter, R. B.-Tollenaar, M. (1982): Effect of temperature during grain filling on whole plant and grain yield in maize (Zea mays L.). Canadian Journal of Plant Science 63: 357-363.

Bellini, P.-Fusi, G. (1961): Rese individual ed unitarie dei diversi organi epigei in 1961 (Zea mays L.). Elette. 7. 1: 28-40.

Berzsenyi Z. (2009): A kukorica termésnövekedésének agronómiai és fiziológiai összefüggései. Agrofórum Extra. 27: 14-18.

Bunting, E. S. (1976): Accumulated temperature and maize development in England. Journal Agronomic Science. Cambridge. 87: 577-583.

Carter, M. W.-Poneleit, C. G. (1973): Black Layer Maturity and Filling Period Variation Among inbred Lines of Corn ( $\mathrm{Zea}$ mays L.) Canadian Journal of Plant Science. 68: 597-606. 
Cross, H. Z.-Zuber, M. S. (1972) Prediction of flowering dates in maize based on different methods of estimating thermal units. Agronomic Journal. 64: 351-355.

Daynard, T. B.-Duncan, V. G. (1969): De la germination sous des degres divers de temperature constante. Crop Science. 473-476.

Dobos A. Cs. (2003): Eltérő genotípusú kukorica hibridek szemtermésének szárazanyag-beépülés és vízleadás dinamikája. Doktori (PhD) értekezés tézisei. DE AGTC. Debrecen.

Dobos, A. Cs.-Szabó, G. (2005): Water loss dynamics in maize hybrids with different genotypes. Acta Agraria Hungarica. 53. 2: $153-159$.

Duncan, W. G.-Hatfield, A. L.-Ragland, J. L. (1965): The growth and yield of corn II. Daily growth of corn kernels. Agronomic Journal. 57: 221-223.

Gilmore, E. C.-Rogers, J. S. (1958): Heat unit as a method of measuring maturity in corn. Agronomic Journal. 50: 611-615.

Hallauer, A. R.-Russell, W. A. (1961) Effects of selected weather factors on grain moisture reduction from silking to physiologic maturity in corn. Agronomy Journal. 53: 225-229

Hanft, J. M.-Jones, R. J.-Stume, A. B. (1986): Dry matter accumulation and carbohydrate concentration patterns of fieldgrown and in vitro cultured maize kernels from tip and middle ear positions. Crop Science. 9: 803-804.

Hicks, D. R.-Geadelmann, J. L.-Peterson, R. H. (1976): Drying rates of froster maturing maize. Agronomy Journal. 68: 452455

Jones, R. J.-Gegenbach, B. B.-Cardwell, V. B. (1981) Temperature effects on in vitro kernel development of maize. Crop Science. 21: 761-766.

Kang, M.S.-Zuber, M. S.-Colbert, T. R.-Horroks, R. D. (1986) Effects of certain agronomic traits on and relationship between grain-moisture reduction and grain fill during the filling period in maize. Field Crop Res. 14: 339-347.

Kiesselbach, T. A. (1950): Progressive development and seasonal variation of corn crop. University of Nebraska Bulletin. 166.
Máthéné G. G. (1989): A különböző N- anyagcsere hatása a szemfejlödés folyamataira, külön tekintettel a szemnedvességtartalom dinamikkájára opaque-2 és normál genotípusoknál. Kandidátusi értekezés. Kompolt.

Pepó P.-Karancsi L. G.-Novák A. (2016): Kukorica genotípusok tápanyag-reakciója és vízhasznosítása eltérő évjáratokban. Növénytermelés. 65. 4: 71-84.

Quattar, S.-Jones R. J.-Crookstone, R. K.-Kajelou, M. (1987a): Effects of water deficit during grain filling on the pattern of maize kernel growth and development. Crop Science. 27: 730735.

Quattar, S.-Jones R. J.-Crookstone, R. K.-Kajelou, M. (1987b): Effect of drought on water relation of developing maize kernels. Crop Science. 27: 730-735.

Ragland, J. L.-Hatfield, A. L.-Beniot, G. R. (1965): The growth and yield of corn. I. Microclimate effects on the growth rate. Agron. Journal. 57: 217-220.

Ritchie, J. T.-Sing, U.-Godwin, D. C.-Humpries, J. (1994): Ceres cereal generic model. FortranSource Code. Michigan State University. East-Lansing.

Sárvári M.-Bene E. (2015): Az NPK tápanyag-gazdálkodás helyzete és fejlesztési lehetőségei termésdepresszió ellen. Agrárunió. 16. 2: 38.

Schmidt, T. L.-Hallauer, A. R. (1966): Estimating harvest date of corn in the field. Crop Science. 6: 227-231.

Tollenaar, M -Daynard, T. B -Hunter, R. B. (1979): Effect of temperature on rate of leaf appearance and flowering date in maize. Crop Science. 19: 363-366.

Tollenaar, M.-Bruulsema, T. W. (1988) Effect of temperature on rate and rate duration of kernel dry matter accumulation of maize. Canadian Journal Plant Science. 68: 935-939.

Wilson, J. H.-Cloves, M. S.-Allison, J. C. (1973): Growth and yield of maize at different attitudes in Rhidesia. Ann. Appl. Biol. 73: $77-84$. 